\title{
SEX AND AGE FACTORS IN ACUTE AND CHRONIC VALVULAR DISEASE
}

\author{
BY \\ H. L. SHEEHAN AND A. M. SUTHERLAND * \\ From the Research Department, Glasgow Royal Maternity and Women's Hospital \\ Received May 26, 1939
}

In a pathological study of cardiac disease in pregnancy, controls were needed from women of child-bearing age who were not pregnant. This raised the question of the influence of the sex or age of patients on the various aspects of valvular disease. It is, however, difficult to get satisfactory pathological information on this point. Clinical studies of these factors have been made by Gillespie (1898), Andrew (1909), MacDonald (1914), and Willius (1926) ; some pathological details are included, but they are inadequate for the present purpose. The accuracy of clinical diagnosis of chronic valve lesions is a little over 50 per cent., as shown by Cabot (1926) and Frey (1936), so that the information from clinical studies about the sex and age differences of the valve lesions is not sufficiently reliable. There are certain relevant pathological data in the papers of Cabot (1914 and 1926), Coombs (1924), and Cowan and Ritchie (1935), which are discussed later, but much of the information we required is not given by these authors.

An analysis was therefore made of the records of 11,700 consecutive autopsies in two large general hospitals and one children's hospital in Glasgow, the numbers of males and females being approximately equal. In these cases clinical and pathological details were abstracted of the 1057 patients that showed post mortem any chronic or acute valve lesions, excluding minor senile changes in the aortic valve. The few patients in these general hospitals who died during pregnancy or within eight weeks of delivery are excluded from this control series.

No investigation has been made of the microscopic appearances of the valves or heart muscle, so this limits the scope of our figures to lesions which are obvious to the naked eye. Certain of the pathological and clinical records may be incomplete, but this source of potential error appears insufficient to vitiate the general conclusions. No attempt has been made to assess the severity of the mechanical defects of the valve, a severe mitral stenosis and an incompetence due to minor scarring both being classed as chronic mitral lesions.

* Working with the aid of the Medical Research Council and the Robert Jardine Research Scholarship. 
The valve lesions are considered under the headings of :

I. Chronic valve lesions, i.e. scarring of valves that is apparently of rheumatic type.

II. Recurrent endocarditis, i.e. simple acute vegetations on old scarred valves or on valves that were previously healthy in a heart with old chronic valvular disease.

III. Simple acute endocarditis, i.e. vegetations of rheumatic type in a heart without recognizable chronic lesions.

IV. Ulcerative or subacute bacterial endocarditis, whether on previously damaged valves or not.

V. Lesions of the aortic valve, either syphilitic or of the senile variety classed as primary sclerosis.

\section{CHRONIC VALVE LESIONS}

Excluding aortic lesions due to senile sclerosis or syphilis, 629 patients had scarring of one or more valves, producing stenosis or incompetence, and of the type usually accepted as due to old rheumatic involvement. Often there was a superadded simple acute or ulcerative endocarditis ; these will be discussed later.

The incidence of chronic rheumatic valvular disease was much higher in adults than in children. There were 596 cases in 7000 necropsies on patients aged 12 and over (8.5 per cent.), but only 33 out of 4700 in children under $12(0.7$ per cent.). These figures are slightly higher than those of Davis and Weiss (1932), who found 222 out of 3951 necropsies on patients 10 years old and over (5.6 per cent.) and only 4 out of 821 in children under $10(0.5$ per cent.).

\section{Sex AND Age Differences}

The distribution of chronic lesions on the different valves has been studied by various authors (Edens, 1929), but no differentiation with regard to sex or age is found in their data, except in the work of Cabot (1926), who gives details of 208 patients.

In the present series the sex and age incidence of chronic lesions affecting $(a)$ the mitral alone, $(b)$ the aortic and mitral together, and $(c)$ the aortic-mitraltricuspid or the mitral-tricuspid, are plotted in Figs. 1 and 2 ; the number with each valve lesion being shown as a percentage of the total with any chronic valve lesion in the given age group and of that sex. The main points shown are the high relative incidence of aortic-mitral lesions in males, and of pure mitral lesions or of multiple valve lesions involving the tricuspid in females.

The number of cases is shown in Table I. From these it will be seen that the incidence of pure mitral and of mitral-tricuspid lesions is much greater in females than in males; nearly three times up to the age of 25 , and nearly twice over that age. 


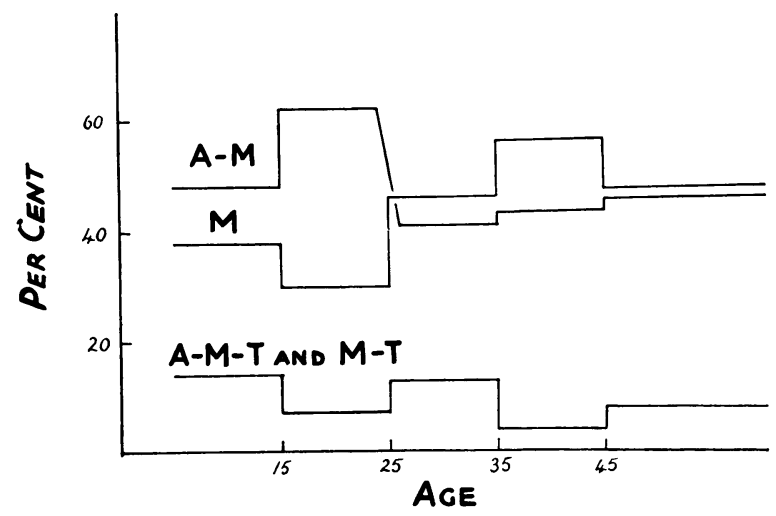

Fig. 1.-Percentage distribution of chronic valve lesions at different ages in males. M denotes mitral lesions ; A-M, combined aortic and mitral lesions, etc.

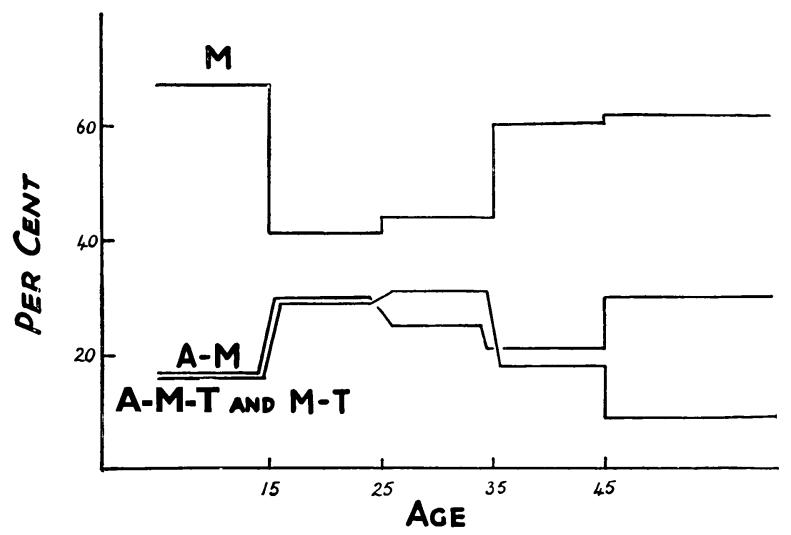

Fig. 2.-Percentage distribution of chronic valve lesions at different ages in females (see Fig 1).

TABLE I

Sex and Age Incidence of Chronic Valve Lesions

\begin{tabular}{|c|c|c|c|c|c|c|c|}
\hline Sex & Age & $\mathbf{M}^{*}$ & A-M & A-M-T & M-T & A & Others \\
\hline \multirow[t]{2}{*}{ Males } & $\begin{array}{c}\text { to } 15 \\
16 \text { to } 25 \\
26 \text { to } 35 \\
36 \text { to } 45 \\
\text { Over } 45\end{array}$ & $\begin{array}{r}8 \\
9 \\
18 \\
26 \\
44\end{array}$ & $\begin{array}{l}10 \\
19 \\
16 \\
21 \\
45\end{array}$ & $\begin{array}{l}3 \\
1 \\
4 \\
1 \\
5\end{array}$ & $\begin{array}{l}0 \\
1 \\
1 \\
1 \\
3\end{array}$ & $\begin{array}{r}3 \\
3 \\
8 \\
12 \\
16\end{array}$ & $\begin{array}{c}\text { P-T } \\
\text { P-T } \\
0 \\
0 \\
\text { A-M-P }\end{array}$ \\
\hline & Total & 105 & 111 & 14 & 6 & 42 & 3 \\
\hline \multirow[t]{2}{*}{ Females } & $\begin{array}{c}\text { to } 15 \\
16 \text { to } 25 \\
26 \text { to } 35 \\
36 \text { to } 45 \\
\text { Over } 45\end{array}$ & $\begin{array}{l}24 \\
18 \\
21 \\
41 \\
84\end{array}$ & $\begin{array}{r}6 \\
13 \\
12 \\
14 \\
41\end{array}$ & $\begin{array}{l}3 \\
7 \\
9 \\
7 \\
8\end{array}$ & $\begin{array}{l}3 \\
6 \\
6 \\
6 \\
4\end{array}$ & $\begin{array}{l}1 \\
3 \\
1 \\
5 \\
4\end{array}$ & $\begin{array}{c}0 \\
0 \\
0 \\
\text { M-T-P } \\
0\end{array}$ \\
\hline & Total & 188 & 86 & 34 & 25 & 14 & 1 \\
\hline
\end{tabular}

* In this and all tables, M, A, T, and P stand for mitral, aortic, tricuspid and pulmonary valve lesions, and A-M, etc., for combined aortic and mitral lesions, etc. 
On the other hand, a combined aortic-mitral lesion, including those with aortic-mitral-tricuspid involvement, shows the same absolute incidence in males and in females at every age group. The relative incidence is, however, higher in males.

The tricuspid is involved nearly three times as often in females as in males. A pure tricuspid lesion has not been observed ; it is more commonly associated with aortic-mitral than with mitral lesions. The two pulmonary-tricuspid lesions in young males were, as usually, associated with congenital heart disease.

Pure aortic lesions are rare in females but much commoner in males, particularly over 25 , though some lesions in older males are open to the suspicion of being really due to primary sclerosis or syphilis.

Cabot (1926) noted the same predominance of mitral lesions in females and of aortic lesions in males. He found the aortic-mitral lesion more common in males than in females, but this is not striking in the present series if aorticmitral-tricuspid is included with aortic-mitral disease.

\section{Age at Death}

The age at which patients die with various chronic valve lesions is about the same for pure mitral and for combined mitral and aortic lesions (Table I). On the other hand, patients with a tricuspid lesion superimposed tend to die much earlier, usually before the age of 35 . The age of death with each valve lesion showed no essential difference between the sexes. Cabot (1926) considered that males tended to die earlier from mitral or combined lesions than females ; this does not agree with the present data.

\section{Mode OF DeATH}

This is of importance not only with regard to the chronic valve lesion, but also with regard to the incidence of recurrent endocarditis. Clinically the patients have been classified into the following six groups according to the manner of death.

Progressive Failure.-Patients with typical congestive heart failure, with the usual signs becoming gradually worse until death ; post mortem, chronic venous congestion of the lungs and abdominal viscera, and usually pulmonary infarcts ; no clinical or pathological evidence of any complicating disease.

Failure Combined with Other Illnesses.-Patients with typical congestive failure, combined with pathological evidence of some complicating disease. In some the major factor causing death was the failure, in others the intercurrent disease ; a few have been included that died of sudden heart failure, apparently without any gross congestion previously.

Acute Rheumatism or Chorea.-Patients with acute rheumatism or chorea at the time of death or during the previous six months. The expression " acute rheumatism " is used to indicate rheumatic fever, and does not include growing pains, sore throats, or tonsillitis. Many of the patients in this group died with clinical and pathological evidence of failure, but they are not included in the first two groups. 
Intercurrent Illness.-Patients with no history or post-mortem evidence of failure, who died from other illnesses such as pneumonia or carcinoma, excluding rheumatism.

Sudden, Violent Death.-Patients that died suddenly as a result of street accident or suicide, nearly half of them before the age of 45. Apart from having old scarred valves, they appear to have been in normal health.

Ulcerative Endocarditis.-All patients with any chronic valve lesion in whom a superadded ulcerative endocarditis was found at death. Some died of failure, others of septicæmia or intercurrent disease; but all have been excluded from the previous groups.

\section{Relation of Valve Lesions to Mode of Death}

When the patients are considered according to the valves affected by the chronic lesion, there are certain striking differences in the mode of death. The actual numbers are shown in Table II. The chief points are the low incidence of failure in men with pure mitral lesions, the high incidence of failure in tricuspid lesions, and the high incidence of ulcerative endocarditis in chronic aortic lesions.

TABLE II

Type of Death with each Chronic Valve Lesion

\begin{tabular}{|c|c|c|c|c|c|c|}
\hline Sex & & Type of Death & $\mathbf{M}$ & A-M & $\begin{array}{c}\text { A-M-T and } \\
\text { M-T }\end{array}$ & A \\
\hline Males .. & $\ldots$ & $\begin{array}{l}\text { Failure, simple and com- } \\
\text { bined, and rheumatism } \\
\text { Intercurrent disease and } \\
\text { violence } \\
\text { Ulcerative endocarditis }\end{array}$ & $\begin{array}{r}41 \\
56 \\
9\end{array}$ & $\begin{array}{l}62 \\
33 \\
16\end{array}$ & $\begin{array}{r}18 \\
1 \\
1\end{array}$ & $\begin{array}{l}13 \\
14 \\
15\end{array}$ \\
\hline Females & . & $\begin{array}{l}\text { Failure, simple and com- } \\
\text { bined, and rheumatism } \\
\text { Intercurrent disease and } \\
\text { violence } \\
\text { Ulcerative endocarditis }\end{array}$ & $\begin{array}{r}117 \\
56 \\
14\end{array}$ & $\begin{array}{r}54 \\
25 \\
7\end{array}$ & $\begin{array}{r}55 \\
3 \\
2\end{array}$ & $\begin{array}{l}5 \\
5 \\
6\end{array}$ \\
\hline
\end{tabular}

The more important age differences are that 80 per cent. of the deaths due to intercurrent disease without failure were in patients over 35 , and that the ulcerative aortic lesions were commoner among the older men.

Cabot (1926) observed death from failure in only two thirds of his chronic tricuspid cases, which is less than in the present series, apparently because only one of his seveu patients with mitral-tricuspid lesions had failure. In the present series there were 31 patients with mitral-tricuspid lesions, of whom 20 died of pure, and 6 of complicated failure.

\section{RECURRENT ENDOCARDITIS}

Of the 629 cases with chronic rheumatic valvular lesions, 71 had a superadded ulcerative endocarditis (see later). In the remaining 558, 244 had simple acute 
vegetations, either on the scarred valves or, less frequently, on previously undamaged valves. This is referred to as recurrent endocarditis. This incidence of recurrent endocarditis in 46 per cent. of the chronic cases is in reasonable agreement with the findings of previous workers, whose combined data on 710 cases give an incidence of 40 per cent. : Gerhardt (1913), Coombs (1924), Cabot (1926), Clawson, Bell, and Hartzell (1926), Stone and Feil (1933), and Cowan and Ritchie (1935).

Pathologically the vegetations are indistinguishable from those of the various forms of simple acute endocarditis, and appear to have essentially the same ætiological factors. But they are much more liable to develop in a previously damaged heart than simple endocarditis in a normal one. This matter is well discussed by Gross and Friedberg (1936). It is difficult to form any good estimate of the age of the recurrent vegetations. Clinically they cannot be diagnosed during life except by inference, and generally are not recognized till after death. Histologically they are hyaline or fibrinoid masses of from 1 to $4 \mathrm{~mm}$. in height, sometimes with, and sometimes without organization at their base ; while organization certainly indicates advancing age of the lesion, the rate at which it progresses in this situation is unknown.

\section{CAuse of Death}

The chief data on the incidence of recurrent endocarditis are shown in Table III, divided into sections according to the various clinical factors.

TABLE III

Relationship of Recurrent Endocarditis to Age and to Type of Death

\begin{tabular}{|c|c|c|c|c|c|c|c|c|c|c|}
\hline \multirow{2}{*}{ Age } & \multicolumn{2}{|c|}{$\begin{array}{l}\text { Progressive } \\
\text { Failure }\end{array}$} & \multicolumn{2}{|c|}{$\begin{array}{c}\text { Failure } \\
\text { Combined }\end{array}$} & \multicolumn{2}{|c|}{$\begin{array}{c}\text { Acute } \\
\text { Rheumatism }\end{array}$} & \multicolumn{2}{|c|}{$\begin{array}{l}\text { Intercurrent } \\
\text { Illness }\end{array}$} & \multicolumn{2}{|c|}{$\begin{array}{l}\text { Violent } \\
\text { Death }\end{array}$} \\
\hline & $\mid \begin{array}{c}\text { Total } \\
\text { Chronic }\end{array}$ & $\begin{array}{l}\text { Recurr. } \\
\text { End. }\end{array}$ & $\begin{array}{c}\text { Total } \\
\text { Chronic }\end{array}$ & $\begin{array}{l}\text { Recurr. } \\
\text { End. }\end{array}$ & $\begin{array}{c}\text { Total } \\
\text { Chronic }\end{array}$ & $\begin{array}{c}\text { Recurr. } \\
\text { End. }\end{array}$ & $\begin{array}{c}\text { Total } \\
\text { Chronic }\end{array}$ & $\begin{array}{l}\text { Recurr } \\
\text { End. }\end{array}$ & $\mid \begin{array}{c}\text { Total } \\
\text { Chronic }\end{array}$ & $\begin{array}{l}\text { Recurr. } \\
\text { End. }\end{array}$ \\
\hline $\begin{array}{l}\text { To } 15 \\
16 \text { to } 25 \\
26 \text { to } 35 \\
36 \text { to } 45 \\
\text { Over } 45\end{array}$ & $\begin{array}{l}29 \\
37 \\
43 \\
52 \\
87\end{array}$ & $\begin{array}{l}25 \\
22 \\
20 \\
20 \\
36\end{array}$ & $\begin{array}{r}2 \\
8 \\
9 \\
14 \\
33\end{array}$ & $\begin{array}{r}1 \\
6 \\
7 \\
6 \\
11\end{array}$ & $\begin{array}{r}26 \\
14 \\
5 \\
3 \\
2\end{array}$ & $\begin{array}{r}21 \\
14 \\
5 \\
0 \\
1\end{array}$ & $\begin{array}{r}0 \\
9 \\
22 \\
46 \\
98\end{array}$ & $\begin{array}{r}0 \\
4 \\
11 \\
13 \\
20\end{array}$ & $\begin{array}{r}0 \\
4 \\
3 \\
2 \\
10\end{array}$ & $\begin{array}{l}0 \\
0 \\
0 \\
0 \\
1\end{array}$ \\
\hline Total & 248 & 123 & 66 & 31 & 50 & 41 & 175 & 48 & 19 & 1 \\
\hline
\end{tabular}

Progressive Failure.-Fifty per cent. of these cases had a recurrent endocarditis. This high incidence appears significant, though it is not clear whether the recurrence is due to the failure, or whether it indicates a carditis which caused the failure. Most patients before the final cardiac failure have temporary failure and recovery several times, when it seems probable that acute vegetations are frequently present. Davis and Weiss (1931) also noted the high incidence of acute vegetations in patients who died of failure, but they did not give figures. Gerhardt (1913) found recurrent endocarditis in 11 out of 23 cases with failure. 
Failure combined with Other Illnesses.-Recurrent endocarditis was found in forty-seven per cent. of the cases, practically the same figure as in the pure failure group.

Acute Rheumatism or Chorea.-Eighty-two per cent. of the cases with acute rheumatism at the time of death or during the previous few months had recurrent lesions. But there are a certain number, particularly children, with no recurrent vegetations, though these are to be expected with active rheumatism. Karsner and Bayless (1934) in a study of hearts with Aschoff nodes found recurrent endocarditis in 39 of 51 cases with old valve lesions. The data given by Rothschild, Kugel, and Gross (1934), and by Werner (1936) with regard to the incidence of active infection of the heart in rheumatic fever cannot be compared with the present figures, as they did not deal with the incidence of acute endocarditis. Acute rheumatism is not usually fatal, and probably most cardiac patients who have subsequent attacks of acute rheumatism develop a recurrent endocarditis at these times.

Patients who gave a history of acute rheumatism many years previously did not show any striking incidence of recurrent endocarditis, when due regard was given to sex, age, and manner of death. This agrees with Frey (1936), who also points out that its incidence diminishes with the passage of time since the last attack of acute rheumatism.

Intercurrent Illnesses excluding Rheumatism.-Twenty-seven per cent. of these cases had a recurrent endocarditis. The intercurrent disease that caused death was often of a type such as pneumonia from which recovery is usual. Thus it appears probable that, during passing illnesses, many patients with old valvular disease develop a recurrent endocarditis which is not clinically recognized and heals later. There is no clear evidence as to whether this is due to a flare up of a quiescent rheumatic infection in the heart or to a new infection due to the intercurrent disease. These diseases were of the same types and were found in the same relative proportions in recurrent endocarditis as in simple acute endocarditis in patients with hearts previously normal, who had died of intercurrent disease. The outstanding difference was in the incidence of the acute vegetations ; they were found in 27 per cent. of the patients who had old chronic valvular disease, and only in 1.5 per cent. of 10,643 patients with hearts previously normal.

The existence of this group is in itself sufficient evidence that a recurrent endocarditis does not always cause failure.

Sudden, Violent Death.-Among the 19 cases with chronic valve lesions in this group, the only one with recurrent endocarditis was an old man. These figures are small, but give no support to the theory that, in a person with an old valvular lesion but otherwise in good health, there may be frequent recurrent endocarditis without any exciting factor. This conclusion depends, of course, on the supposition that the vegetations are not rapidly evanescent.

\section{EfFect of AgE AND SeX}

Age.-Running right across these clinical factors is the great variation due to the age of the patient. The percentage of patients in each age group who 
TABLE IV

ReCURrent Endocarditis at Various Ages

\begin{tabular}{rrr|c|c|c}
\hline \multicolumn{2}{c|}{ Age } & & $\begin{array}{c}\text { Total } \\
\text { Chronic } \\
\text { Valve Lesions }\end{array}$ & $\begin{array}{c}\text { Recurrent } \\
\text { Endocarditis }\end{array}$ & Percentage \\
\hline 4 to 7 &. &. & 17 & 15 & 88 \\
8 to 11 &. &. & 16 & 13 & 81 \\
12 to 15 &. &. & 25 & 19 & 76 \\
16 to 25 &. &. & 71 & 46 & 65 \\
26 to 35 &. &. & 81 & 43 & 33 \\
36 to 45 &. &. & 118 & 69 & 30 \\
Over 45 &. &. & 230 & 69 & \\
\hline
\end{tabular}

showed recurrent lesions is given in Table IV. These are very close to the percentages given by Coombs (1924) from a study of 98 necropsies; his figures, which appear to be the only ones published, range from 88 per cent. under 10 years to 24 per cent. over 40 years of age. The high incidence of acute rheumatism and of death from progressive failure is probably responsible for the height of the figures in the earlier age groups, but there appears to be a true diminution in the incidence of recurrent endocarditis in older patients, quite apart from this. When the patients in each clinical group are considered separately, as in Table III, a similar steady reduction of the incidence of recurrent endocarditis with advancing age is obvious.

Sex.-There were 93 cases among 240 male patients with chronic valve lesions, and 151 cases among 318 females. It is, however, not satisfactory to compare the gross incidence of recurrent endocarditis in males with that in females without regard to the significant factors; the high incidence of acute rheumatism and of failure in females distorts the picture. When the cases are grouped on a clinical basis there is no obvious difference between the sexes except in the deaths from progressive failure (Table V). In this condition the incidence of recurrent endocarditis falls suddenly at about 15 years of age in

TABLE V

Sex Differences of Recurrent Endocarditis in Decompensation

\begin{tabular}{|c|c|c|c|c|c|c|}
\hline \multirow{2}{*}{ Age } & \multicolumn{3}{|c|}{ Males } & \multicolumn{3}{|c|}{ Females } \\
\hline & $\begin{array}{c}\text { Total } \\
\text { Chronic }\end{array}$ & $\begin{array}{c}\text { Recurrent } \\
\text { Endocarditis }\end{array}$ & Percentage & $\begin{array}{c}\text { Total } \\
\text { Chronic }\end{array}$ & $\begin{array}{c}\text { Recurrent } \\
\text { Endocarditis }\end{array}$ & Percentage \\
\hline $\begin{array}{ll}\text { To } 15 & \ldots \\
16 \text { to } 25 & \ldots \\
26 \text { to } 35 & \ldots \\
36 \text { to } 45 & \ldots \\
\text { Over } 45 & \ldots\end{array}$ & $\begin{array}{l}10 \\
15 \\
20 \\
21 \\
25\end{array}$ & $\begin{array}{l}9 \\
6 \\
6 \\
8 \\
7\end{array}$ & $\begin{array}{l}90 \\
40 \\
30 \\
38 \\
28\end{array}$ & $\begin{array}{l}19 \\
22 \\
23 \\
31 \\
62\end{array}$ & $\begin{array}{l}16 \\
16 \\
14 \\
12 \\
29\end{array}$ & $\begin{array}{l}84 \\
73 \\
61 \\
39 \\
47\end{array}$ \\
\hline
\end{tabular}


males, but not until about 35 in females. This sex difference is significant for the original purpose of this study, the provision of control figures for the investigation of cardiac disease in pregnancy.

\section{VALVES AfFeCted}

The valves affected by the acute recurrent vegetations are shown in Table VI, grouped according to the previous chronic valve lesion; the figures show the actual number of cases with each lesion.

TABLE VI

VALVES AFFECTED By RECURRENT ENDOCARDitis MALES

\begin{tabular}{|c|c|c|c|c|c|c|c|c|c|}
\hline \multirow{2}{*}{\multicolumn{4}{|c|}{$\begin{array}{l}\text { Recurrent } \\
\text { Endocarditis }\end{array}$}} & \multicolumn{6}{|c|}{ Chronic Valve Lesion } \\
\hline & & & & M & A-M & A-M-T & M-T & A & Others \\
\hline None & . & .. & . & 63 & 53 & 7 & 3 & 20 & P-T \\
\hline $\begin{array}{l}\text { M } \\
\text { A-M } \\
\text { A-M-T } \\
\text { M-T } \\
\text { A } \\
\text { Others }\end{array}$ & $\begin{array}{l}. . \\
\ldots \\
\ldots \\
. \\
.\end{array}$ & $\begin{array}{l}. \\
. \\
. \\
. \\
. \\
. .\end{array}$ & $\begin{array}{l}. \\
. \\
. \\
. \\
.\end{array}$ & $\begin{array}{r}\mathbf{2 1} \\
4 \\
5 \\
0 \\
3 \\
\text { A-P }\end{array}$ & $\begin{array}{r}11 \\
23 \\
3 \\
0 \\
3 \\
\mathrm{~T}, \mathrm{~A}-\mathrm{T}\end{array}$ & $\begin{array}{l}2 \\
2 \\
1 \\
1 \\
1 \\
0\end{array}$ & $\begin{array}{l}1 \\
0 \\
0 \\
1 \\
0 \\
0\end{array}$ & $\begin{array}{l}0 \\
0 \\
3 \\
0 \\
4 \\
0\end{array}$ & $\begin{array}{c}\text { A-M-P } \\
0 \\
0 \\
0 \\
0 \\
0\end{array}$ \\
\hline
\end{tabular}

Females

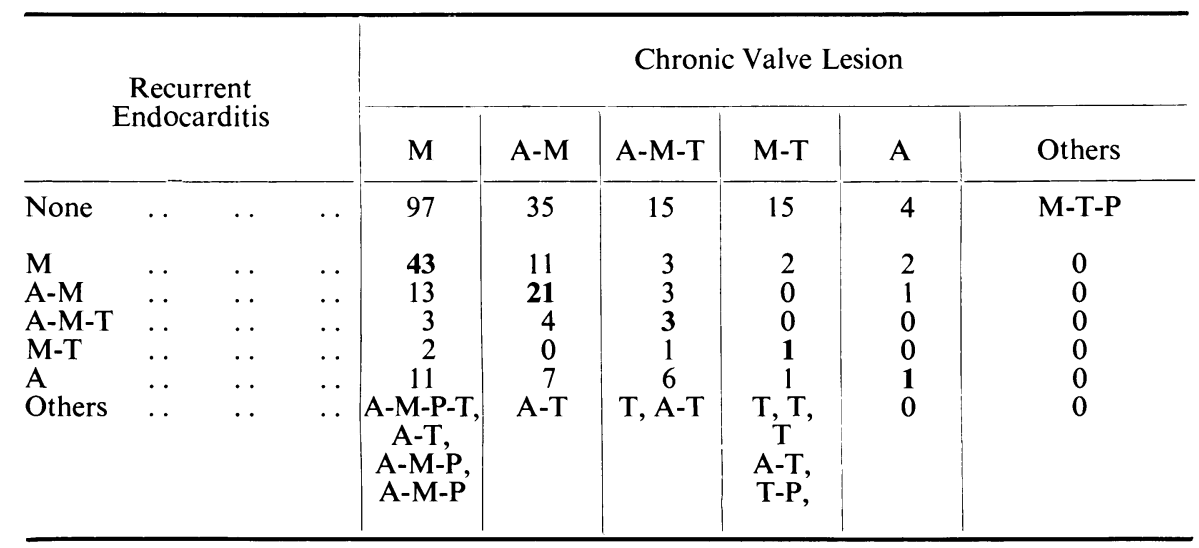

Previously Fibrosed Valves.-Recurrence occurred on 36 per cent. of the 522 fibrosed mitral valves, on 35 per cent. of the 257 fibrosed aortic valves, and on 19 per cent. of the 79 fibrosed tricuspid valves. This rough proportion of $2: 2: 1$ in the incidence of recurrence on mitral : aortic : tricuspid holds good for any subdivision of the cases according to sex, age, or mode of death, though the actual percentages are influenced by these factors. This relative immunity 
of the tricuspid to recurrent endocarditis may be connected with the relative immunity of this valve to endocarditis in general.

These findings have a bearing on the question of recurrence on chronic lesions of multiple valves... In chronic aortic-mitral lesions the recurrence affects both fibrosed valves more frequently than one. In chronic mitraltricuspid and aortic-mitral-tricuspid lesions recurrence on three or even two valves is much less frequent than recurrence on either valve separately.

Spread to Fresh Valves. - If there are fibrosed valves in a heart, the other healthy valves show a great tendency to develop an acute endocarditis, as compared with a heart in which none of the valves have been scarred (see Table VII). The valve incidence of this spreading endocarditis is about $3: 3: 1$ for mitral : aortic : tricuspid, which is very similar to the $2: 2: 1$ figure for recurrence on scarred valves. This proportion holds in all the clinical subdivisions. Generally this spread to fresh valves is associated with recurrent endocarditis on one or more of the scarred valves- 46 of the 255 cases where there was a recurrent endocarditis. Occasionally, however, the acute endocarditis affects normal valves without any recurrence on the fibrosed valves19 cases, 15 of which were women; here the acute endocarditis affected only the aortic, and the fibrosed mitral or tricuspid had no recurrent lesions.

TABLE VII

Recurrent Endocarditis Spreading to New Valves

\begin{tabular}{|c|c|c|c|c|c|c|}
\hline \multirow{2}{*}{$\begin{array}{l}\text { Non- } \\
\text { scarred } \\
\text { Valve }\end{array}$} & \multicolumn{3}{|c|}{$\begin{array}{c}\text { Hearts with Previously Damaged } \\
\text { Valves }\end{array}$} & \multicolumn{3}{|c|}{ Hearts Previously Normal } \\
\hline & Total & $\begin{array}{c}\text { Spreading } \\
\text { Endocarditis }\end{array}$ & $\begin{array}{l}\text { Percen- } \\
\text { tage }\end{array}$ & Total & $\begin{array}{l}\text { Simple Acute } \\
\text { Endocarditis }\end{array}$ & $\begin{array}{l}\text { Percen- } \\
\text { tage }\end{array}$ \\
\hline $\begin{array}{l}\text { Mitral .. } \\
\text { Aortic . } \\
\text { Tricuspid. . }\end{array}$ & $\begin{array}{r}36 \\
301 \\
479\end{array}$ & $\begin{array}{r}6 \\
46 \\
25\end{array}$ & $\begin{array}{r}16 \cdot 6 \\
15 \cdot 3 \\
5 \cdot 2\end{array}$ & $\begin{array}{l}10,643 \\
10,643 \\
10,643\end{array}$ & $\begin{array}{r}126 \\
82 \\
12\end{array}$ & $\begin{array}{l}1 \cdot 2 \\
0 \cdot 8 \\
0 \cdot 1\end{array}$ \\
\hline
\end{tabular}

Age and Sex Incidence.-A spread to new valves occurs most frequently with a pure chronic mitral lesion, as these patients have, of course, more unaffected valves than patients with multiple old lesions (a chronic aortic lesion of rheumatic type is relatively uncommon). Thus, as shown in Table VI, the spread is absolutely more frequent in females, in view of the higher number of pure chronic mitral lesions in that sex. When, however, the incidence is considered in relation to the number of cases in which spread was possible, there does not appear to be any significant sex difference in the valves affected. The age factor is much the same as in recurrent endocarditis, there being a gradual decrease in the proportionate incidence with advancing age.

The spreading lesion shows a relationship to the type of death similar to that of recurrent endocarditis in general ; it occurs in about one-third of the patients dying of acute rheumatism or of failure and in about one-seventh of the patients dying of intercurrent diseases. 


\section{SIMPLE ACUTE ENDOCARDITIS}

Simple acute endocarditis is used here to mean any vegetations which are not obviously ulcerative or subacute bacterial, and where there is no chronic valve lesion macroscopically recognizable. As in recurrent endocarditis, the vegetations are small hyaline or fibrinoid masses about 1 to $4 \mathrm{~mm}$. in height. It seems probable that they can develop in a few days, since they are sometimes found after quite short illnesses. A differentiation of these vegetations into rheumatic, as opposed to non-bacterial thrombotic or terminal, is made by some authors on the basis of the size and exuberance of the vegetations, as well as on the histology. While the non-rheumatic vegetations are sometimes large, the vegetations of all types are presumably small in the early stages, so no attempt has been made to subdivide the group on pathological appearances; any subdivision here has been made on clinical grounds alone.

Though cases of ulcerative endocarditis have been excluded from this group, a few classified as simple acute endocarditis may really have been the early stages of the former. The difficulty of naked eye diagnosis is illustrated where there is a gross ulcerative endocarditis on one valve and also apparently simple vegetations on the same valve or on others. The co-existence of simple and ulcerative endocarditis on the same valve and the difficulty of differentiating them in the early stages by naked eye are discussed by Clawson and Bell (1926) and by Von Glahn and Pappenheimer (1935).

The numbers in the present series showing simple acute endocarditis are shown in Table VIII ; its rarity in children under 3 is referred to by Norris (1911) and de Vecchi (1931).

TABLE VIII

Age INCIDENCE OF ACUTE ENdocarditis

\begin{tabular}{|c|c|c|}
\hline $\mathrm{Ag}$ & & $\begin{array}{l}\text { Cases with Acute } \\
\text { Endocarditis }\end{array}$ \\
\hline $\begin{array}{l}\text { To } 3 \\
4 \text { to } 7 \\
8 \text { to } 11 \\
12 \text { to } 15 \\
16 \text { to } 25 \\
26 \text { to } 35 . \\
36 \text { to } 45 \\
\text { Over } 45 .\end{array}$ & $\begin{array}{l}\ldots \\
\ldots \\
\ldots \\
\ldots \\
\ldots \\
\ldots \\
\ldots\end{array}$ & $\begin{array}{r}4 \\
14 \\
14 \\
11 \\
15 \\
13 \\
23 \\
66\end{array}$ \\
\hline
\end{tabular}

\section{ÆTIOLOGY}

The clinical conditions at or shortly before death are given in Table IX ; they are similar to those found with recurrent endocarditis in patients that die without failure.

Acute rheumatism or chorea is most frequently found in the young, and among these it is almost twice as common in females as in males.

The miscellaneous group includes pyogenic infections such as pneumonia, meningitis, and burns, and a variety of conditions such as toxic goitre and tuberculosis ; a history of acute rheumatism or chorea was not obtained in any 
of these. Apart from a high incidence in young girls, there is no obvious sex difference. This group also includes three surprising cases, patients who were killed accidentally, and post mortem were found to have small vegetations on the aortic or mitral ; two were young adults. It is not possible to say whether there had been any minor illnesses, such as tonsillitis, before the fatal accident.

The remaining group of uræmia, hypertension, and carcinoma naturally provides most of the cases in later life. This type is usually referred to as terminal, and it is unlikely that any of these could have recovered. There is no obvious sex difference.

TABLE IX

Ætiology of Acute Endocarditis

\begin{tabular}{|c|c|c|c|c|c|c|c|}
\hline \multirow{2}{*}{ Ætiological Factor } & \multirow{2}{*}{ Sex } & \multicolumn{6}{|c|}{ Age } \\
\hline & & To 15 & $16-25$ & $26-35$ & $36-45$ & Over 45 & Total \\
\hline $\begin{array}{l}\text { Acute rheumatism or } \\
\text { chorea }\end{array}$ & $\begin{array}{l}\text { Male } \\
\text { Female }\end{array}$ & $\begin{array}{l}11 \\
15\end{array}$ & $\begin{array}{l}1 \\
3\end{array}$ & $\begin{array}{l}0 \\
1\end{array}$ & $\begin{array}{l}1 \\
1\end{array}$ & $\begin{array}{l}1 \\
2\end{array}$ & $\begin{array}{l}14 \\
22\end{array}$ \\
\hline Miscellaneous & $\begin{array}{l}\text { Male } \\
\text { Female }\end{array}$ & $\begin{array}{c}4 \\
13\end{array}$ & $\begin{array}{l}4 \\
3\end{array}$ & $\begin{array}{l}5 \\
5\end{array}$ & $\begin{array}{l}2 \\
6\end{array}$ & $\begin{array}{l}17 \\
14\end{array}$ & $\begin{array}{l}32 \\
41\end{array}$ \\
\hline $\begin{array}{l}\text { Uræmia, hypertension, } \\
\text { or carcinoma }\end{array}$ & $\begin{array}{l}\text { Male } \\
\text { Female }\end{array}$ & $\begin{array}{l}0 \\
0\end{array}$ & $\begin{array}{l}2 \\
2\end{array}$ & $\begin{array}{l}1 \\
1\end{array}$ & $\begin{array}{l}4 \\
9\end{array}$ & $\begin{array}{l}19 \\
13\end{array}$ & $\begin{array}{l}26 \\
25\end{array}$ \\
\hline
\end{tabular}

\section{Valves AfFected}

There is no difference between the valves affected by chorea and those affected by rheumatism : see Table $X$, where they are grouped according to

TABLE $X$

Valves affected by Acute Endocarditis

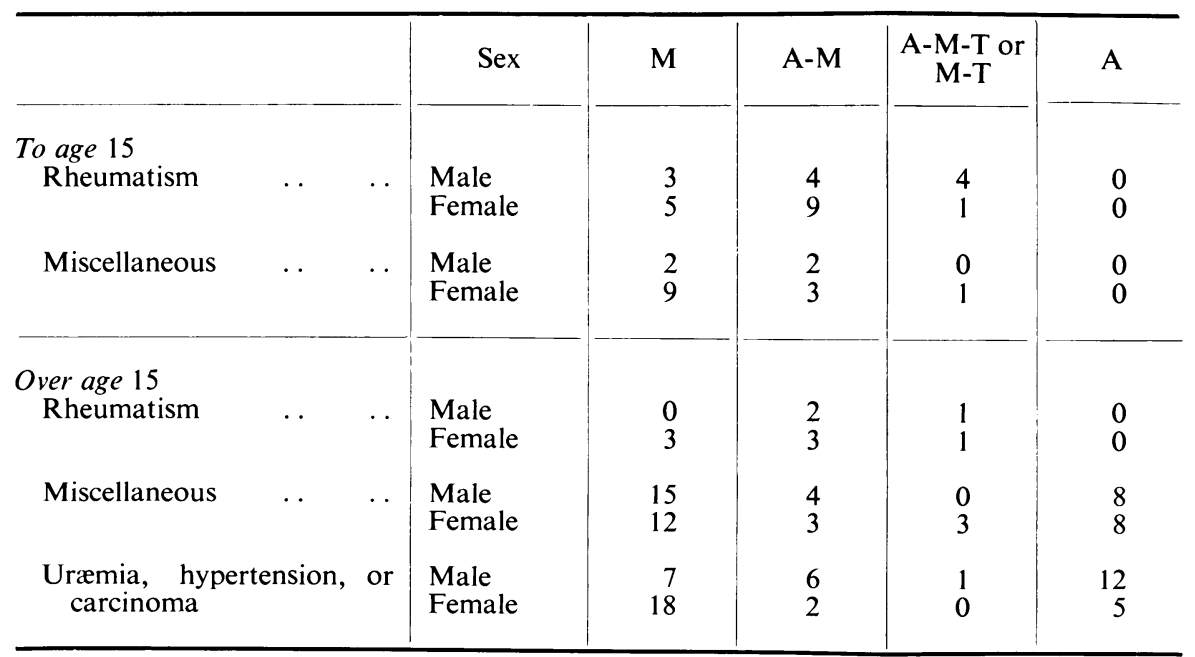


ætiological factors. In children, most of the acute endocarditis is due to rheumatism, with the striking exception of pure mitral lesions in girls, which are more frequently not associated with rheumatism. Below the age of 15 rheumatism never causes an acute aortic lesion alone in either sex, but frequently an acute aortic-mitral lesion, particularly in girls. Over the age of 15 , most of the acute endocarditis is not rheumatic in origin. After 35 there is a striking increase of pure mitral lesions, mainly in women, and also of pure aortic lesions, mainly in men.

\section{ULCERATIVE AND SUBACUTE ENDOCARDITIS}

The term "ulcerative endocarditis" is used to cover not only the true ulcerative or malignant lesions but also subacute bacterial endocarditis of Streptococcus viridans type. The subject is well reviewed by Blumer (1923), Horder (1926), Thayer (1926), and Segal (1936). Though early ulcerative endocarditis may be hard to distinguish macroscopically from simple endocarditis, the fully developed, large, friable vegetations are quite characteristic. The cases included as subacute bacterial endocarditis are classified as occurring on previously damaged valves. They are selected on a pathological basis and not on the criterion adopted by Clawson, Bell, and Hartzell (1926) of a clinical history of over six weeks. This difference may account for the very high incidence of subacute endocarditis in certain American clinics, e.g. 60 per cent. of all hearts in which there was any valve lesion (Clawson, 1924).

It is not clear how often the ulcerative lesion begins as such or how often as a further development on previously simple acute vegetations ; there is a considerable weight of evidence that it may develop on simple recurrent endocarditis, as has been shown by Von Glahn and Pappenheimer (1935). It is of interest in this connection to note the great frequency of joint pains in the very early stages of the illness, without any septic arthritis, and before any recognizable embolic phenomena have developed.

\section{Developing on Valves Previously Normal}

Primary ulcerative endocarditis is relatively uncommon in children up to 11 ; in the present series there were 9 out of 4700 autopsies $(0.2$ per cent.), whereas over that age it was found 89 times in 7000 autopsies (1.3 per cent.). In adults the main point of interest is the biphasic incidence-very frequent up to 25 , and then later, over 45 . The cases in youth or early middle age were all septicæmic in origin or clinical course : over 45 , about half were of septicæmic type, but the others were incidental findings post mortem in patients dying from other diseases-carcinoma of stomach, 8 cases ; other carcinomas, mainly of biliary tract, 5 cases ; uræmia due to prostatic enlargement or renal calculi, 6 cases ; miscellaneous conditions, 4 cases.

There is a slightly higher incidence in males than in females, related to differences in the valves affected: pure aortic lesions affected males almost exclusively; the mitral was involved alone about twice as often as the com- 
bined aortic-mitral; the pulmonary, which was hardly ever the site of simple endocarditis, was sometimes affected by the ulcerative lesion, particularly when there was a congenital basis or a spread to all the valves. None of the present cases appeared to be related to clinical gonorrhœa. There is no obvious valve difference between the septicæmic and the non-septic types. The numbers showing each valve lesion are grouped in Table XI according to sex and age. Some of the older patients may have had early senile changes in the aortic valve, which predisposed them to an ulcerative lesion, but this does not explain the high incidence of mitral lesions in the older men.

TABLE XI

UlCERATIVE ENDOCARDITIS ON Normal VALVes

\begin{tabular}{|c|c|c|c|c|c|c|c|c|}
\hline & & Age & $\mathbf{M}$ & A-M & A-M-T & A & Others & Total \\
\hline Males & $\ldots$ & $\begin{array}{c}\text { To } 15 \\
16 \text { to } 25 \\
26 \text { to } 35 \\
36 \text { to } 45 \\
\text { Over } 45\end{array}$ & $\begin{array}{r}5 \\
5 \\
2 \\
0 \\
14\end{array}$ & $\begin{array}{l}0 \\
2 \\
1 \\
1 \\
5\end{array}$ & $\begin{array}{l}0 \\
1 \\
0 \\
0 \\
1\end{array}$ & $\begin{array}{l}2 \\
5 \\
1 \\
5 \\
4\end{array}$ & $\begin{array}{c}\text { A-M-P-T; } \\
\mathbf{P} \\
\text { M-T-P } \\
0 \\
\text { A-T }\end{array}$ & $\begin{array}{r}9 \\
14 \\
5 \\
6 \\
25\end{array}$ \\
\hline Females & .. & $\begin{array}{c}\text { To } 15 \\
16 \text { to } 25 \\
26 \text { to } 35 \\
36 \text { to } 45 \\
\text { Over } 45\end{array}$ & $\begin{array}{l}5 \\
4 \\
4 \\
2 \\
4\end{array}$ & $\begin{array}{l}3 \\
5 \\
0 \\
0 \\
5\end{array}$ & $\begin{array}{l}0 \\
0 \\
0 \\
0 \\
1\end{array}$ & $\begin{array}{l}0 \\
0 \\
0 \\
0 \\
2\end{array}$ & $\begin{array}{c}0 \\
\text { A-T } ; P \\
M-T \\
0 \\
T\end{array}$ & $\begin{array}{r}8 \\
11 \\
5 \\
2 \\
13\end{array}$ \\
\hline
\end{tabular}

\section{Developing on Previously Damaged Valves}

In 42 per cent. of the 169 cases with ulcerative endocarditis a pre-existing chronic valve lesion was recognized, and possibly in some others the ulcerative endocarditis had destroyed any evidence of previous scarring. The frequency with which previously scarred valves are affected by ulcerative endocarditis is greater in males than females ; 17 per cent. of 240 males and 9 per cent. of 318 females. A similar sex incidence was noted by Davis and Weiss (1931); 20 per cent. of 272 males and 10 per cent. of 213 females. When the sexes are not differentiated an intermediate figure is found ; 12 per cent. of 348 patients with previously scarred valves in the combined series of Stone and Feil (1933), Frey (1936), and Epstein and Schwedel (1938).

Table XII shows that in males the incidence rose sharply at about 25 , i.e.

TABLE XII

Age and Sex Incidence of Ulcerative Endocarditis on Scarred Valves

\begin{tabular}{|c|c|c|c|c|}
\hline \multicolumn{3}{|c|}{ Age Group } & Males & Females \\
\hline $\begin{array}{l}\text { To } 15 \\
16 \text { to } 25 \\
26 \text { to } 35 \\
36 \text { to } 45 \\
\text { Over } 45\end{array}$ & $\begin{array}{l}\ldots \\
\cdots \\
\cdots \\
\ldots\end{array}$ & $\begin{array}{l}\ldots \\
\ldots \\
\ldots \\
\ldots\end{array}$ & $\begin{array}{r}3 \\
4 \\
12 \\
11 \\
12\end{array}$ & $\begin{array}{r}1 \\
6 \\
3 \\
6 \\
13\end{array}$ \\
\hline
\end{tabular}


the age when the fall occurs in the number with hearts previously normal: in females the incidence was relatively low except in people over 45 . All but 5 of the 25 cases over 45 were septicæmic in type.

The numbers with each individual valve lesion are shown in Table XIII. In more than a quarter there was a spread of the ulcerative lesion to valves that had previously been undamaged. The frequency with which any chronic rheumatic valve lesion was affected by ulcerative endocarditis is also shown in this table. Ulcerative endocarditis affects about 36 per cent. of patients that have a pure chronic aortic lesion of rheumatic type, and this holds good when the cases are analysed according to sex or age ; it is the same in young women as in older men, though, of course, the absolute numbers of chronic aortic lesions are much higher in the male group. In chronic mitral or aortic-mitral lesions ulcerative endocarditis occurs in about 10 per cent. of cases, again without any significant sex or age differences. The low incidence of ulcerative endocarditis on the aortic in chronic aortic-mitral lesions, as compared with its higher incidence in chronic aortic lesions without fibrosis of the mitral, is of interest. White (1937) has suggested that there is a relationship between the degree of stenosis of the mitral and the tendency for ulcerative endocarditis to affect this valve, but we have not investigated this. In contrast to the other valves, patients with chronic tricuspid lesions show a very low susceptibility to ulcerative endocarditis, only about 4 per cent. ; the total incidence is actually less than that of ulcerative endocarditis on the tricuspid in patients with no chronic lesion of this valve. This may be because patients with chronic tricuspid lesions die earlier in life. Libman (1923) has shown that ulcerative endocarditis is relatively common on the tricuspid, as compared with subacute bacterial endocarditis. His total figures of 16 tricuspid involvements out of 156 cases of ulcerative and subacute bacterial endocarditis are in reasonable agreement with the present: figures : 12 tricuspid involvements out of 169 cases of ulcerative or subacute bacterial endocarditis, with or without a previous chronic lesion.

TABLE XIII

Ulcerative Endocarditis on SCARred Valves

\begin{tabular}{|c|c|c|c|c|c|c|c|c|}
\hline \multirow{2}{*}{\multicolumn{3}{|c|}{$\begin{array}{l}\text { Ulcerative } \\
\text { Endocarditis }\end{array}$}} & \multicolumn{6}{|c|}{ Chronic Valve Lesions } \\
\hline & & & $\mathbf{M}$ & A-M & A-M-T & M-T & A & Others \\
\hline None & . & . & 270 & 174 & 47 & 29 & 37 & 3 \\
\hline $\begin{array}{l}\text { M .. } \\
\text { A-M } \\
\text { A-M-T } \\
\text { M-T } \\
\text { A .. } \\
\text { Others }\end{array}$ & $\begin{array}{l}. \\
\cdots \\
\cdots \\
\cdots \\
\cdots \\
\cdots\end{array}$ & $\begin{array}{l}\ldots \\
\ldots \\
\ldots \\
\ldots \\
\ldots \\
\ldots\end{array}$ & $\begin{array}{r}14 \\
5 \\
2 \\
1 \\
1 \\
0\end{array}$ & $\begin{array}{r}4 \\
13 \\
0 \\
0 \\
6 \\
0\end{array}$ & $\begin{array}{l}1 \\
0 \\
0 \\
0 \\
0 \\
0\end{array}$ & $\begin{array}{l}1 \\
1 \\
0 \\
0 \\
0 \\
0\end{array}$ & $\begin{array}{r}0 \\
8 \\
1 \\
0 \\
\mathbf{1 1} \\
\mathrm{A}-\mathrm{T}\end{array}$ & $\begin{array}{c}0 \\
0 \\
0 \\
0 \\
0 \\
\text { P-T } \\
\text { (cong.) }\end{array}$ \\
\hline
\end{tabular}

\section{PRIMARY AORTIC SCLEROSIS AND SYPHILIS}

Lesions of the aortic valve due to syphilis or primary sclerosis are only important in the present study because they have to be differentiated from the $2 \mathrm{~A}$ 
rheumatic lesions; only exceptionally does this provide any difficulty. The two conditions were nearly all found in patients over 45 , though syphilitic cases were sometimes seen in the previous decade. After excluding all minor senile changes, the actual numbers were as follows-primary sclerosis : males 58 , females 17 ; syphilis : males 82 , females 14 .

Small vegetations due to a superimposed acute endocarditis were present in four of the syphilitic and in eight of the sclerosis cases. This appears to be a chance complication, the incidence being roughly similar in the syphilitic patients and in those with otherwise normal hearts dying in the same age periods. The slightly higher incidence among the sclerosis cases is probably spurious, depending on the initial exclusion of many cases with minor thickening of the aortic, but without any acute vegetations. Gerhardt (1913) found a recurrent endocarditis in two out of eleven arteriosclerotic valves.

\section{DISCUSSION}

It is accepted pathologically that vegetations on a valve are frequently an indication of an acute valvulitis which may go on to scarring later. This applies particularly to acute rheumatism. On the other hand, it is impossible to say what might have occurred subsequently, if a patient with advanced carcinoma could have recovered after having developed a terminal endocarditis. There is, however, a large group, intermediate between acute rheumatism and terminal endocarditis, that includes not only simple endocarditis but also endocarditis recurring or spreading to other valves. Though, of course, all the patients in this intermediate group had died, most of them were suffering from diseases not necessarily fatal; it is in these that the subsequent fate of the valve is in doubt.

These hearts do not have the microscopic changes in the myocardium that characterize acute rheumatism, but this cannot be accepted as proof that scarring of the valve will not occur. The mere occurrence of the vegetations suggests co-existing acute valvulitis that could be the basis of subsequent fibrosis. If such scarring occurred on a previously normal valve, it would provide a reasonable explanation for a number of the cases of chronic valvular disease that originate in patients with no ascertainable history of acute rheumatism ; if it developed from a recurrent endocarditis on a previously scarred valve, the mechanical lesion would be aggravated. There is also the complementary question of how often cases of acute valvulitis that leads to subsequent scarring of the valves may run their course without ever developing any vegetations on the valves. This is an important problem in children, as has been shown by de Vecchi (1931).

The significance of recurrent endocarditis is especially doubtful. Is it (a) a terminal condition, or (b) an occasional development in the presence of certain exciting factors, or $(c)$ an intermittent process coming and going unsuspected for many years after the original heart lesion, without any particular causation apart from the continued and symptomless presence of the aetiological agent of rheumatism, or $(d)$ a serious complication of chronic valvular lesions 
that commonly causes death from the associated myocardial damage (Cowan and Ritchie, 1935)?

A study of the present kind might have given some answer to these questions in view of the marked differences in the valves affected by acute or chronic lesions at different ages and in different sexes. There are, however, many difficulties in attempting any correlation. Account must be taken of four factors which may play a part in the distribution of the various types of valve lesions at different ages. First, the age at the onset, which is only known in a certain number. Secondly, the progress of the lesion; if the case starts early, it seems more likely that it will progress on the affected valve and also spread to new valves than if it starts in later life; this presumption is based on the age incidence of recurrent endocarditis. Thirdly, the age at which the valve lesion causes death, e.g. patients with a tricuspid lesion usually die earlier than patients who have not. Fourthly, a factor that has not been discussed, the severity of the individual valve lesion. It is, therefore, not possible to assume that the patients dying in any age group provide a representative sample of the cardiac population at that age. Nevertheless the group of children up to the age of 15 is probably subject to the least complications, and may be used for an attempt to find some correlation between acute or recurrent endocarditis on the one hand and chronic valve lesions on the other. The fundamental problem is how frequently chronic valve lesions are the sequel of acute endocarditis or are aggravated by a recurrent endocarditis. Such a recurrent endocarditis might be assumed for purposes of discussion to develop occasionally at intervals during the patient's life, as a result of temporary failure or intercurrent illness, and to have the same incidence on previously scarred valves or spreading to normal valves as is found post mortem.

Mitral and Aortic-Mitral Lesions in Childhood.-First the ratio of lesions affecting only the mitral to lesions affecting the aortic and mitral together. In girls up to 15 , acute endocarditis without previous valve lesions involves both valves together just as frequently as the mitral alone. But during this age period in girls a chronic lesion affects the mitral alone three times as frequently as the aortic and mitral together. No satisfactory explanation for this preponderance of the pure chronic mitral lesion in girls can be given from a study of the acute endocarditis. On the other hand, in boys up to 15 the correlation is good ; the aortic and mitral are affected together very slightly more frequently than the mitral alone, both by simple endocarditis and by chronic lesions.

Mitral and Aortic-Mitral Lesions in Young Adults.-In girls up to 15 about one third of the patients with chronic mitral lesions have post mortem a spread of acute endocarditis to the aortic. Any fibrosis following these new vegetations ought to lead to an increase of chronic aortic-mitral lesions at the expense of chronic mitral lesions in the next decade. This is the case ; there are rather more chronic aortic-mitral lesions than mitral lesions post mortem in females between the ages of 16 and 25 , in contrast to the findings in young girls. In boys up to 15 there are relatively few pure chronic mitral lesions and less than one fifth of these have spread to the aortic. Theoretically this should only cause 
a slight increase in the ratio of chronic aortic-mitral to chronic mitral lesions in the next decade : this is again the case.

Tricuspid Lesions.-There is thus some suggestion that these spreading vegetations do lead to subsequent fibrosis in the case of the aortic. But when the tricuspid is under consideration this view completely fails to explain the facts : taking the figures for all ages ; $(a)$ the incidence of simple acute endocarditis on this valve was identical in both sexes, 6 males and 6 females ; $(b)$ in the presence of other chronic valve lesions, spread of acute vegetations to this valve was also the same in both sexes, 12 males and 12 females; but $(c)$ the incidence of chronic tricuspid lesions was about three times as high in females as in males, 60 females and 22 males.

In view of these difficulties even in young subjects, no attempt will be made here to explain the increasing incidence of chronic mitral lesions relative to other chronic valve lesions in older women.

\section{RHEUMATIC LESIONS}

In Childhood.-The relation of the valve lesion to a history of rheumatism also presents difficulties. The preliminary consideration may be restricted to children up to 15 (Table XIV). In boys the proportion with acute endo-

TABLE XIV

Relationship of Rheumatism to Valve Lesions in Childhood

\begin{tabular}{|c|c|c|c|c|c|}
\hline Sex & Valve & $\begin{array}{c}\text { Cases of } \\
\text { Acute } \\
\text { Endocarditis }\end{array}$ & $\begin{array}{c}\text { Acute } \\
\text { Rheumatism } \\
\text { at Death }\end{array}$ & $\begin{array}{l}\text { Chronic } \\
\text { Valve } \\
\text { Lesions }\end{array}$ & $\begin{array}{c}\text { History of } \\
\text { Rheumatism }\end{array}$ \\
\hline \multirow[t]{2}{*}{ Males under 15} & $\begin{array}{c}\text { M } \\
\text { A-M } \\
\text { A-M-T or } \\
\text { M-T }\end{array}$ & $\begin{array}{l}5 \\
6 \\
4\end{array}$ & $\begin{array}{l}3 \\
4 \\
4\end{array}$ & $\begin{array}{r}8 \\
10 \\
3\end{array}$ & $\begin{array}{l}5 \\
8 \\
2\end{array}$ \\
\hline & Total & 15 & 11 & 21 & 15 \\
\hline \multirow[t]{2}{*}{ Females under $15 \ldots$} & $\begin{array}{c}\text { M } \\
\text { A-M } \\
\text { A-M-T or } \\
\text { M-T }\end{array}$ & $\begin{array}{r}14 \\
12 \\
2\end{array}$ & $\begin{array}{l}5 \\
9 \\
1\end{array}$ & $\begin{array}{r}24 \\
6 \\
6\end{array}$ & $\begin{array}{r}18 \\
5 \\
4\end{array}$ \\
\hline & Total & 28 & 15 & 36 & 27 \\
\hline
\end{tabular}

carditis of any particular valve or valves and acute rheumatism in the few weeks before death is much the same as the proportion with a corresponding chronic lesion and acute rheumatism some years before. In girls this holds good for lesions of combined valves. But there is a striking difference with pure mitral lesions, where, though three-quarters of the chronic lesions have a history of rheumatism, as with other valves and in boys, only about one-third of the cases of acute endocarditis are related to rheumatism. The figures are small, but the difference seems significant. 
The other contrast is as follows. In acute endocarditis due to rheumatism in boys or in girls, the mitral is affected alone in about one-third of the cases and the other two-thirds show multiple valve lesions. In chronic valve lesions following rheumatism this also holds good in boys, the mitral being affected alone in about one-third. In girls, on the other hand, such lesions affect the mitral alone in two-thirds and only one-third are multiple valve lesions.

Subsequent Fate.-Theoretically, the longer the patient lives after the original valve lesion, the more he will be exposed to attacks of recurrent or spreading endocarditis; and, if these lead to fibrosis, the greater the liability to multiple chronic valve lesions. But, when the cases of heart disease dating from acute rheumatism are studied with regard to the duration of life after the onset of the heart lesion, there is no evidence of any development of chronic lesions on fresh valves with the passage of time. The valve distribution shows the same sex differences, whether the rheumatism dates from early in life or later, and whatever the duration of life since the first attack of rheumatism. Table XV shows the

TABLE XV

Chronic Valve Lesions following Rheumatism

\begin{tabular}{|c|c|c|c|c|c|c|}
\hline \multirow{2}{*}{\multicolumn{2}{|c|}{ Sex }} & \multirow{2}{*}{$\begin{array}{l}\text { Chronic } \\
\text { Valve } \\
\text { Lesion }\end{array}$} & \multicolumn{2}{|c|}{$\begin{array}{l}\text { Acute Rheumatism } \\
\text { before } 15\end{array}$} & \multicolumn{2}{|c|}{$\begin{array}{l}\text { Acute Rheumatism } \\
\text { after } 15\end{array}$} \\
\hline & & & $\begin{array}{c}\text { Death within } \\
10 \text { Years }\end{array}$ & $\begin{array}{c}\text { Death over } \\
10 \text { Years } \\
\text { later }\end{array}$ & $\begin{array}{c}\text { Death within } \\
10 \text { Years }\end{array}$ & $\begin{array}{l}\text { Death over } \\
10 \text { Years } \\
\text { later }\end{array}$ \\
\hline Males & $\ldots$ & $\begin{array}{c}\text { M } \\
\text { A-M } \\
\text { A-M-T or M-T } \\
\text { A }\end{array}$ & $\begin{array}{l}5 \\
8 \\
2 \\
0\end{array}$ & $\begin{array}{r}4 \\
10 \\
3 \\
1\end{array}$ & $\begin{array}{l}3 \\
9 \\
0 \\
1\end{array}$ & $\begin{array}{r}4 \\
10 \\
1 \\
2\end{array}$ \\
\hline Females & . $\quad \ldots$ & $\begin{array}{c}\text { M } \\
\text { A-M } \\
\text { A-M-T or M-T } \\
\text { A }\end{array}$ & $\begin{array}{r}18 \\
5 \\
4 \\
0\end{array}$ & $\begin{array}{r}15 \\
6 \\
2 \\
0\end{array}$ & $\begin{array}{r}12 \\
5 \\
3 \\
1\end{array}$ & $\begin{array}{r}12 \\
4 \\
7 \\
0\end{array}$ \\
\hline
\end{tabular}

valve distribution of the chronic lesions of 157 cases in which the date of the first attack of rheumatism was known. The valve incidence of the chronic lesions that date from rheumatism is almost the same throughout life when each sex is considered separately. On the other hand, as has been shown earlier, there are quite marked age differences when the chronic lesions are considered as a whole, i.e. those following acute rheumatism and those without any such history. This raises the possibility that the cases following rheumatism may have a completely different valve distribution at various ages from those not following rheumatism. Taking all the chronic valve lesions of Table I the percentages in which a history of acute rheumatism was obtained are shown in Table XVI. The general fall with advancing age is probably partly due to a failure of memory by the patient, but this explanation will not account satisfactorily for the strikingly low figures in the case of pure mitral lesions in males over 15 years of age. 
TABLE XVI

Percentage of Chronic Lesions with Prevlous Rheumatism

\begin{tabular}{ll|r|r|r|r|r|r|r|r}
\hline \multirow{2}{*}{ Age Group } & \multicolumn{4}{c|}{ Males } & \multicolumn{4}{c}{ Females } \\
\cline { 3 - 8 } & & M & A-M & A-M-T or M-T & A & M & A-M & AM-T- or M-T & A \\
\hline To 15 &. & 63 & 80 & 66 & 0 & 75 & 83 & 66 & 0 \\
16 to 35 &. & 3 & 54 & 86 & 18 & 46 & 56 & 46 & 25 \\
Over 35 &. & 9 & 27 & 20 & 4 & 29 & 31 & 44 & 0 \\
\hline
\end{tabular}

Consideration of the cases with a history of chorea does not show any striking differences from the findings for rheumatism in general, apart from a high sex incidence in females, most marked before the age of 25 . There does not appear to be any association with any specific valve lesion. When all the chronic lesions are taken together, there was a history of chorea and of other acute rheumatism in 1 and 26 per cent. respectively of the males, and in 5 and 35 per cent. of the females. These figures are rather lower than those of Dunn and Hedley (1938), but they do not give details about the age and sex.

It will be seen that every attempt at correlation of chronic valve lesions with acute or recurrent endocarditis breaks down in some fundamental aspect, and that no satisfactory explanation can be offered for the sex and age differences in the various valve lesions. Nevertheless these differences appear to be important and to be of some definite significance.

\section{SUMMARY}

A statistical analysis was made of the pathological and clinical findings in 1057 necropsies on patients with acute or chronic valvular lesions, to ascertain the sex and age differences.

Chronic Rheumatic Valve Lesions.-There was a very high incidence of pure mitral lesions in young girls and of combined lesions affecting the tricuspid in women from 15 to 35 . In males, combined aortic-mitral lesions were common throughout life, but tricuspid involvement was rare. The age of death in chronic mitral lesions was about the same as in chronic aortic-mitral lesions, but patients with chronic tricuspid lesions tended to die much earlier, nearly always as a result of congestive failure.

Recurrent Endocarditis.- Simple acute vegetations, developing on an old valve lesion or, less often, spreading to previously undamaged valves, were very common in childhood but progressively less frequent with advancing age. This recurrent endocarditis was rather more frequent in females; it was very common in acute rheumatism or congestive failure, but was sometimes found with intercurrent diseases. The mitral and aortic were involved with about equal frequency, the tricuspid less commonly.

Simple Acute Endocarditis.-This was rare under 5 years of age. It was more common in older children, associated with acute rheumatism or chorea or 
sometimes with acute infections or septic conditions. In adults the endocarditis was usually associated with infections or miscellaneous conditions ; in old age it was usually a terminal occurrence in carcinoma or cardiorenal disease. In acute rheumatism the lesion usually affected multiple valves : in non-rheumatic cases it usually affected the mitral alone, particularly in females, or the aortic alone, particularly in males ; combined lesions were uncommon.

Ulcerative and Subacute Endocarditis.-This was rather commoner in males than in females. When occurring on previously normal valves it was usually of septicæmic type in early life ; but in old age it was often only terminal, usually in association with carcinoma of the stomach or uræmia.

When developing on previously scarred valves it was commoner in middle life, particularly in males, and was usually of septicæmic type ; it was common on chronic aortic but rare on tricuspid lesions.

Primary Sclerosis and Syphilis.-This affected the aortic valve and was commoner in males than in females.

It is difficult to obtain any real correlation between the incidence of acute endocarditis, recurrent endocarditis, and the chronic valve lesions. Some of the acute lesions may lead to subsequent scarring of the valves, and some of the recurrent lesions to increase of the fibrosis in scarred valves or to the scarring of previously normal valves. The evidence on this matter is, however, inconclusive.

We wish to express our thanks to Professor Shaw Dunn, Professor Blacklock, and Dr. Montgomery for permission to study these autopsy reports.

\section{REFERENCES}

Andrew, J. G. (1909). Age Incidence, Sex and Comparative Frequency in Disease, London. Blumer, G. (1923). Medicine, Baltimore, 2, 105.

Cabot, R. C. (1914). Trans. Ass. Amer. Phys., 29, 22.

(1926). Facts about the Heart, Philadelphia.

Clawson, B. J. (1924). Arch. intern. Med., 33, 157.

Clawson, B. J., and Bell, E. T. (1926). Ibid., 37, 66.

Clawson, B. J., Bell, E. T., and Hartzell, T. B. (1926). Amer. J. Path., 2, 193.

Coombs, C. F. (1924). Rheumatic Heart Disease, Bristol.

Cowan, J. M., and Ritchie, W. T. (1935). Diseases of the Heart, London.

Davis, D., and Weiss, S (1931). Amer. Heart J., 7, 146.

- (1932). Ibid., 8, 182.

Dunn, H. L., and Hedley, O. F. (1938). J. Amer. med. Ass., 110, 1413.

Edens, E. (1929). Die Krankheiten des Herzens und der Gefässe, Berlin.

Epstein, B. S., and Schwedel, J. B. (1938). Amer. Heart J., 15, 316.

Frey, W. (1936). Die Herz und Gefässkrankheiten, Berlin.

Gerhardt, D. (1913). Herzklappenfehler, Vienna.

Gillespie, A. L. (1898). Edinb. Hosp. Rep., 5, 31.

Gross, L., and Friedberg, C. K. (1936). Arch. intern. Med., 58, 620.

Horder, T. (1926). Brit. med. J., 1, 603, 641 and 733.

Karsner, H. T., and Bayless, F. (1934). Amer. Heart J., 9, 557.

Libman, E. (1923). J. Amer. med. Ass., 80, 813.

MacDonald, D. (1914). Glasg. med. J., 81, 12.

Norris, G. W. (1911). Studies in Cardiac Pathology, Philadelphia and London.

Rothschild, M. A., Kugel, M. A., and Gross, L. (1934). Amer. Heart J., 9, 586.

Segal, M. S. (1936). Ibid., 11, 309.

Stone, C. S., and Feil, H. S. (1933). Ibid., 9, 53. 
Thayer, W. S. (1926). Johns Hopk. Hosp. Rep., $22,1$.

de Vecchi, B. (1931). Arch. Path. Lab. Med., 12, 49.

Von Glahn, W. C., and Pappenheimer, A. M.(1935). Arch. intern. Med., 55, 173.

Werner, S. C. (1936). Ibid., 57, 94.

White, P. D. (1937). Heart Disease, New York.

Willius, F. A. (1926). Amer. J. med. Sci., 171, 480. 